\title{
SELF-ASSESSED INTELLIGENCE, PERSONALITY, AND PSYCHOMETRIC INTELLIGENCE: PRELIMINARY VALIDATION OF A MODEL WITH A SELECTED STUDENT POPULATION
}

\author{
Tatiana V. Kornilova, \\ Maria A. Novikova \\ Lomonosov Moscow State University \\ Moscow, Russia
}

In the current study, self-assessed intelligence (SAI) is presented as a multidimensional construct related both to personality and to psychometric intelligence. On the basis of data obtained from a Russian student sample $(N=496)$, the authors validate a structural model in which SAI acts as a mediating variable between latent variables of measured IQ and the trait of acceptance of uncertainty. Evidence for significant gender differences in SAI in favor of men is also given.

Keywords: psychometric intelligence, self-assessed intelligence, gender differences, acceptance of uncertainty.

The concept of self-assessed intelligence (SAI) appeared at the intersection of three major fields of research: studies of self-evaluations and self-esteem, studies of lay (or implicit) theories of intelligence, and studies of intelligence as a general cognitive ability. People's beliefs about the nature of intelligence have an impact on SAI: to be able to estimate one's own or someone else's intelligence one should define what intelligence is and what forms of behavior are intelligent.

Individual differences in IQ have become a prominent topic in the popular science literature; various brochures and on-line programs that offer "fast and accurate" measurement of one's IQ are easily available. It is thus safe to assume that modern laypeople have a relatively formed idea of what intelligence is and how "smart" and intelligent they themselves are.

The first systematic study of lay theories of intelligence was conducted by Flugel in 1947. The distinction between "explicit" and "implicit" theories of intelligence was introduced by Sternberg in the 1980s. 
According to him, explicit theories represent scientific knowledge (they are components of scientific theories developed by certain schools of thought) (Sternberg, 1990). In their study of implicit theories of intelligence in Americans, Sternberg and his colleagues revealed three major factors: verbal intelligence, problem-solving ability, and practical intelligence (Sternberg, Conway, Ketron, \& Bernstein, 1981); the presence of these factors suggests that intelligence is not limited to pure analytical ability.

Analysis of contemporary Russian studies of cognitive ability shows that the concept of SAI is not widely discussed or accepted. A study of the stability of SAI was conducted by Sokolova (1976). The stability/ fluidity of people's conceptions of intelligence was reviewed in a study by Molchanova (2006). Borozdina and Kubantseva (2006) demonstrated the link between SAI and the divergence between self-esteem and level of aspiration. The traditional distinction among cognitive, affective, and behavioral components in studies of self-consciousness (Burns, 1982; Chesnokova, 1977) has not been made in the development of the SAI concept in Russian psychology. However, Western psychology has made the question of whether SAI represents more of a cognitive ability or a personality trait (or traits) central in several research programs.

Thus, according to Chamorro-Premuzic and Furnham, SAI is a subjective perception of intelligence that can account for a significant portion of success in various areas (2006a, 2006b). These authors define SAI as people's insight into the concept of intelligence and their own (and others') level of intelligence; these insights can be revealed through procedures that require people to estimate their own or other people's intelligence.

The correlations between SAI and IQ, personality and gender factors, and academic performance have been the focus of Western psychologists since the turn of the century (Chamorro-Premuzic \& Furnham, 2006a, 2006b; Furnham, 2001; Furnham, Moutafi, \& Chamorro-Premuzic, 2005). Furnham (2001) pointed out that most of the results regarding the correlation of SAI and IQ scores are quite consistent and that the estimates of this correlation usually do not exceed 0.30 . Furnham and his colleagues based a study on the ideas of Cattell (1963), according to whom the development of crystallized intelligence is dependent on social-cultural surroundings and education, while fluid intelligence is determined by individual differences (presumably of an innate charac- 
ter) in the functioning of the central nervous system (Furnham et al., 2005). The authors measured crystallized intelligence with the Wonderlic Personnel Test (WPT) and fluid intelligence with the Baddeley Reasoning Test (BRT). The participants in their study estimated their intellectual ability on the IQ scale, which is based on the bell curve of normal distribution with a mean of 100 and a standard deviation of 15 . Self-evaluation of performance (SEV) after taking the WPT was also examined because the authors believed that it can be taken as a direct indictor of participants' insights into their intellectual abilities. According to their expectations SAI demonstrated significant positive correlations with the WPT $(r=0.27)$; SEV correlated significantly positively with the WPT and the BRT ( $r=0.51$ and $r=0.25$, respectively).

From these results, it becomes clear that psychometrically assessed intellectual ability is one of the major predictors of SAI. The accuracy of prediction is far from perfect however. Holling and Preckel (2005) conclude their review of the studies of the relationship between SAI and psychometric intelligence by stating that "most studies find weak to moderate correlations between self-estimated and tested intelligence... The size of these correlations does not seem to justify the use of selfestimates as a replacement for intelligence tests in vocational counseling” (p. 504). It seems reasonable, therefore, to assume that additional predictors of SAI should exist.

One of the productive avenues of research on predictors of SAI in Western psychology was to look at the relationship between SAI and personality traits, frequently by using the Big Five taxonomy. Furnham previously claimed that theoretically it is possible to develop a link between each of the Big Five traits and measures of intelligence (Furnham et al., 2005). The main findings from the actual studies of such relationships, however, pointed to the existence of the following links: (1) a positive correlation between SAI and Extraversion and Openness, and (2) a negative correlation between SAI and Neuroticism (Ackerman \& Heggestad, 1997; Furnham \& Thomas, 2004).

A relatively large body of literature exists on gender differences in SAI; according to most of them, women tend to estimate their intellectual abilities lower than men do (Furnham, 2001; Furnham et al., 2005; Holling \& Preckel, 2005). Studies carried out with nonstudent samples generally confirmed this finding; for example, in a sample of randomly selected adults men assessed their IQ as being on average 4 to 5 points 
higher than did women (Furnham, 2001). Most authors do not take a clear stand on the causes of the difference between men's and women's SAI. Some of them insist that there are no significant gender differences in psychometrically measured intelligence and that the main driving force behind the gender differences in SAI is social-cultural stereotypes. According to them, men are considered to have higher IQ scores predominantly in the fields of abstract, logical, and spatial thinking (Belof, 1992; Reilly \& Mulhern, 1995).

Others claim that there are significant gender differences in IQ scores (Furnham \& Rawles, 1995a, 1995b). Thus, a team of German psychologists has introduced a hypothesis that gender differences in SAI could be the result of the influence of two independent factors: general cognitive ability and general mathematical ability (Brunner, Krauss, \& Kunter, 2008). The validated model demonstrated significant gender differences in specific mathematical ability favoring boys. This view is not uniformly shared however; others have suggested that a possible source of gender differences in SAI is the higher variability in cognitive ability generally found in men (Deary, Dykiert, \& Gale, 2009). In a previous study, Deary and his colleagues (Deary, Irwing, Der \& Bates, 2007) recruited a cohort of male/female siblings; this procedure enabled them to increase control over genetic and environmental factors (participants were full-blood brothers and sisters, brought up in the same family). The results indicated a very modest advantage for men on the average indicators of the $g$ factor.

Yet another field of research relevant to the topic under investigation is parents' estimates of their children's intelligence. The main trends revealed in this field resemble those observed in the studies of gender differences of SAI: girls' IQs are estimated to be lower than boys.' Kirckaldy, Noack, Furnham, and Siefen, using regression analyses, demonstrated that parents' estimates of their children's IQs depended on the level of the parents' SAI (2007).

Several studies of SAI were conducted to assess its possible correlations with academic performance. The rationale behind such studies is the assumption that subjective confidence in knowledge and ability can positively affect performance (Chamorro-Premuzic \& Furnham, 2006b); this assumption was developed largely on the basis of Bandura's (1997) theory of self-efficacy. In their two-year longitudinal study, Furnham and Chamorro-Premuzic demonstrated that despite the fact that 
the main predictor of academic performance was measured IQ, SAI accounted for a

percentage of the variance in academic achievement (ChamorroPremuzic \& Furnham, 2006b); this finding confirms the suggested positive relationship between SAI and achievement.

Later studies moved from the search for correlations to the testing of models. An example of such a model can be found in a study by Chamorro-Premuzic \& Arteche (Chamorro-Premuzic \& Arteche, 2008). Their model includes the following measured variables: academic performance, SAI, measured IQ (crystallized and fluid), and the Big Five factors of Conscientiousness, Neuroticism, and Openness. In this model, SAI acts as a mediating variable between measured intelligence and academic performance (it is positively linked to both these variables). The established relationship between SAI and gender and the negative correlation of SAI with Neuroticism generally support the results of the studies reviewed above. Academic performance is also positively predicted by measured IQ, Conscientiousness, and Openness.

Being directly dependent on IQ scores, as well as on gender and Neuroticism, SAI affects academic performance. The main conclusion one can reach from this model is that SAI may play a mediating role between variables of intelligence and personality, on the one hand, and academic performance, on the other.

\section{Current Study}

In our study we decided to focus on the first part of this relationship - that of SAI, psychometrical IQ, personality traits, and gender. We assume that defining this relationship can shine light on the "affect and intelligence problem," which has existed in science for more than 300 years. (It was first articulated by Spinoza.) Before we move further in our discussion, several clarifications are necessary.

We believe the problem of SAI cannot be viewed as a stand-alone scientific issue. It should be addressed in the broader context of selfawareness, which, in its turn, is a part of human consciousness. The topic of the relationship between the constructs of consciousness and self-consciousness (or self-awareness) deserves its own research and is not our focus. We refer here only to the classic distinction, established by Mead (1934) and then by Duval and Wicklund (1972), between fo- 
cusing attention outward toward the environment (consciousness) or inward toward the self (self-consciousness). In other words, self-consciousness refers to the capacity to become the object of one's own attention. This concept has much in common with the idea of self-concept, as proposed by Burns (1982). According to Burns, self-concept comprises cognitive, evaluative, and behavioral components. In Russian psychology the distinction between cognitive and affective components has also been implied (Chesnokova, 1977; Stolin, 1983). Self-esteem (of which SAI is a part) is believed to be a part of the evaluative (affective) component of self-consciousness. Self-esteem is usually related to personality traits (or is even considered to be a trait itself: people are considered to have high or low self-esteem). Among personality traits related to SAI Western authors name the Big Five factors. We believe that another possible correlate of SAI is the trait of acceptance of uncertainty. There is a simple explanation for this belief: this personal trait seems to be important in estimating one's own intelligence because the criteria for deciding whether a particular person is smart are not always clear. Thus, a decision needs to be made with regard to what constitutes intelligence and intelligent behavior. Acceptance of uncertainty is a widely discussed trait in contemporary psychological studies, especially in light of results linking it to academic performance, coping strategies, emotional intelligence, intuition, and other variables (Kornilova, Chumakova, Kornilov, \& Novikova, 2011).

Another critical point of our study is the assumption that SAI, as a part of self-esteem, is related not only to personality traits but to cognitive ability as well because an estimated part of self-esteem is intelligence. This assumption is supported by a number of studies in which significant positive correlations between psychometrical intelligence and SAI were obtained.

We believe that SAI might be reviewed as a mediating variable between the domains of cognition and personality ("affect and intelligence"). This pair of variables may not be significantly interrelated, but both variables have significant positive links to the variable of SAI.

In our research the relation between psychometrical IQ, SAI, and acceptance of uncertainty was tested by fitting a structural model in which all three factors were presented as latent factors comprising several measured variables (which reflect different dimensions of the factors). 
The hypotheses of the existence of latent factors and their interrelations were tested with structural equation modeling (SEM). SEM is the main method of analysis that provides a means for visualizing and testing complex hypotheses of the interrelations between both latent and measured variables (Grigorenko, 1994). Among the advantages of SEM is the possibility of handling missing data and multivariate nonnormal data. In addition, SEM cannot be called a purely mathematical method because it has a serious impact on the development of theoretical assumptions, which leads to model reconstruction and modification.

In addition to testing the interrelations among latent variables, we decided to answer a question asked by our Western colleagues: Is SAI dependent on gender, and, if so, does this difference rely on a significant gap between men and women in psychometrical IQ?

In our research the following hypotheses were tested:

$\mathrm{H} 1$ : The latent factor of SAI is positively related to the latent factor of acceptance of uncertainty.

H2: SAI is positively related to the latent variable of intelligence, which comprises the variables of conventional intelligence and of peerestimated intelligence (PEI).

H3: Significant gender differences in SAI exist, although there are no significant differences in measured IQ scores.

\section{Participants}

Five hundred undergraduate students $(71.5 \%$ female, the mean age was $19.40, S D=1.40$ ) from Moscow State University participated in this study in return for course credit. All the participants were white and reported "Russian" as their nationality or refused to report their nationality.

\section{Measures}

Self- and Peer-Estimated Intelligence, Academic Self-Concept

A direct self-assessment of intelligence was administered on the basis of the SAI procedure, as proposed by Chamorro-Premuzic \& Furnham (2006b). The participants were asked to give an estimate of their intelligence in IQ scores. The normal distribution curve of IQ scores was presented to the subjects $(M=100, S D=15)$, with the comment that over $99 \%$ of the population is allocated on the scale within 6 standard deviations. 
To obtain measures of self- and peer-estimated intelligence (Kornilova, Kornilov, \& Chumakova, 2009; Smirnov, Kornilova, Kornilov, \& Malakhova, 2007), students first wrote down the qualities a person should possess in order to be considered clever and then ranked themselves and their classmates by perceived "intelligence" using a class list. A weighted mean rank - a variable of PEI - was computed for each student. The weighted rank that a student assigned to himself or herself was used as a measure of self-estimated intelligence (SEI).

Academic self-concept was measured with Smirnov's (2005) Russian translation of three of Dweck's (1999) brief questionnaires. In the Russian version two scales have been added to the questionnaire, one of them is the SAAP scale, which reflects subjects' estimates of the effort expended on their studies and their success (Kornilova et al., 2008; Smirnov, 2005); $\alpha, 0.72$

\section{Acceptance of Uncertainty}

Readiness for Risk is a personality trait that reflects the self-regulation of decisions and actions in a situation of uncertainty and limited information. This characteristic was measured using a similarly named scale, the Personal Factors in Decision Making Questionnaire (Kornilova, 2003); $\alpha, 0.65$.

Tolerance for Uncertainty - readiness to make decisions and act in uncertain situations and openness to new ideas, changing stimuli, and changing thinking strategies - was tested with the New Questionnaire of Tolerance for Uncertainty (NQTU) (Kornilova, 2009). This Russian questionnaire was constructed and validated by combining four different scales designed for the measurement of Tolerance for Uncertainty (the O'Connor, Rydel-Rosen, Badner, and Norton scales), first introduced by Furnham (1994). Tolerance for Uncertainty is one the three scales of the NQTU; $\alpha, 0.70$.

Trust in one's intuition was measured using the Faith in Intuition scale of the Rational-Experiential Inventory (REI) (Epstein, Pacini, Denes-Raj \& Heier, 1996), validated on a Russian sample (Stepanosova, Kornilova, \& Grigorenko, 2004); a, 0.82.

Cognitive Ability

Verbal and fluid intelligence were tested with the ROADS battery, which is designed for assessing creative, academic, and practical intelligence (Kornilov \& Grigorenko, 2010). The analytical part of the com- 
posite battery consists of the two subtests from Cattell's Culture-Fair Intelligence Test and two verbal scales: the Russian version of the Mill-Hill Vocabulary Scale and the verbal analogies scale.

General IQ was measured with Wonderlic's Cognitive Ability Test (CAT) (formerly, Personnel Test), validated in Russian (Buzin, 1992).

\section{Procedure}

Some of the tests were administered in groups (the ROADS assessment battery, the Group Estimation of Intelligence, the CAT); some were administered individually (the direct self-assessment of intelligence, the REI, the Personal Factors in Decision Making Questionnaire, and the NQTU).

\section{Results}

Table 1 shows the matrix of intercorrelations for the study. Higher direct SAI characterizes participants with higher estimates of measured IQ; a significant correlation is that of SAI and fluid intelligence $(r=0.24$, $p<0.05$ ), which is connected to the operative use of knowledge. Measures of both fluid and verbal intelligence are significantly positively linked to PEI ( $r=-0.27$ and -0.30 , respectively, $p<0.01$ ). PEI is positively related to academic self-concept $(r=-0.28, p<0.01)$. Correlations of measures of group-estimated intelligence (GEI) with other variables suggest positive relations as GEI constructs (PEI and SEI) should be treated inversely (participants are asked to rank their classmates and themselves by perceived "intelligence," so the person who is perceived to be the smartest has the lowest rank estimate, equal to 1).

The significant positive correlation between Tolerance for Uncertainty and SAI $(r=0.22, p<0.01)$ is a novel result. There are two possible ways of interpreting it. First, people who can easily act under the circumstances of lack of information and high uncertainty, which implies high risk, can be aware of this trait and believe that it is associated with their intelligence, and thus they assess their intelligence as being high. Second, people who assess their intelligence as high are confident of their capabilities in a situation of high uncertainty or while solving problems that are new to them.

Based on the collected data, a structural model was constructed for the variables in our study. In this model, three factors are introduced. The intelligence factor comprises fluid and verbal measures, which refer 
Intercorrelations Matrix

Table 1

\begin{tabular}{|c|c|c|c|c|c|c|c|c|c|}
\hline & 1 & 2 & 3 & 4 & 5 & 6 & 7 & 8 & 9 \\
\hline $\begin{array}{l}\text { 1. Readiness for } \\
\text { Risk } \\
N\end{array}$ & $\begin{array}{c}1 \\
320 \\
\end{array}$ & $\begin{array}{c}.26^{* *} \\
270 \\
\end{array}$ & $\begin{array}{l}.24^{* *} \\
265 \\
\end{array}$ & $\begin{array}{l}.10 \\
320 \\
\end{array}$ & $\begin{array}{l}-.11 \\
320\end{array}$ & $\begin{array}{l}-.01 \\
173\end{array}$ & $\begin{array}{l}.08 \\
113\end{array}$ & $\begin{array}{c}-.03 \\
92\end{array}$ & $\begin{array}{c}-.17 \\
92\end{array}$ \\
\hline $\begin{array}{l}\text { 2. Tolerance } \\
\text { for Uncertainty } \\
N\end{array}$ & & 1 & $\begin{array}{c}.30^{\star *} \\
228\end{array}$ & $\begin{array}{c}.22^{\star *} \\
280\end{array}$ & $\begin{array}{c}-.04 \\
83\end{array}$ & $\begin{array}{c}.02 \\
175\end{array}$ & $\begin{array}{l}-.12 \\
114\end{array}$ & $\begin{array}{l}.20 \\
92\end{array}$ & $\begin{array}{l}.03 \\
92\end{array}$ \\
\hline $\begin{array}{l}\text { 3. Faith in } \\
\text { Intuition } \\
\mathrm{N}\end{array}$ & & & 1 & $\begin{array}{r}.10 \\
275 \\
\end{array}$ & $\begin{array}{c}-.58 \\
57 \\
\end{array}$ & $\begin{array}{c}.02 \\
149 \\
\end{array}$ & $\begin{array}{l}.05 \\
80 \\
\end{array}$ & $\begin{array}{c}-.13 \\
67 \\
\end{array}$ & $\begin{array}{c}-.19 \\
67 \\
\end{array}$ \\
\hline $\begin{array}{l}\text { 4. Direct } \\
\text { SAI } \\
\text { N }\end{array}$ & & & & 1 & $\begin{array}{c}-.29 \\
85\end{array}$ & $\begin{array}{r}.23 \\
183 \\
\end{array}$ & $\begin{array}{l}-.12 \\
118 \\
\end{array}$ & $\begin{array}{c}.24^{*} \\
96\end{array}$ & $\begin{array}{l}.16 \\
96 \\
\end{array}$ \\
\hline $\begin{array}{l}\text { 5. SEI (in GEI } \\
\text { procedure) } \\
N\end{array}$ & & & & & 1 & $\begin{array}{c}-.20 \\
67\end{array}$ & $\begin{array}{c}.29 * * \\
85\end{array}$ & $\begin{array}{c}-.21 \\
68\end{array}$ & $\begin{array}{c}-.16 \\
68\end{array}$ \\
\hline $\begin{array}{l}\text { 6. Academic } \\
\text { self-concept } \\
N\end{array}$ & & & & & & 1 & $\begin{array}{c}-.28^{\star *} \\
92\end{array}$ & $\begin{array}{c}.15^{\star} \\
75\end{array}$ & $\begin{array}{l}.02 \\
75\end{array}$ \\
\hline $\begin{array}{l}\text { 7. PEI } \\
N\end{array}$ & & & & & & & 1 & $\begin{array}{c}-.27^{\star *} \\
96\end{array}$ & $\begin{array}{c}-.30^{\star *} \\
96\end{array}$ \\
\hline $\begin{array}{l}\text { 8. Fluid intel- } \\
\text { ligence } \\
N\end{array}$ & & & & & & & & 1 & $\begin{array}{c}.32^{\star *} \\
96\end{array}$ \\
\hline $\begin{array}{l}\text { 9. Verbal intel- } \\
\text { ligence } \\
N\end{array}$ & & & & & & & & & $\begin{array}{c}1 \\
96\end{array}$ \\
\hline
\end{tabular}

to conventional intelligence, and PEI. The SAI factor is defined by direct self-assessment of intelligence, SEI in GEI, and academic self-concept. Thus we conclude that SAI can be represented as a latent variable that includes different measures of a subject's assessments of cognitive ability: direct estimation of intelligence (based on the normal distribution of IQ scores in the population), self-estimation of intelligence in comparison with those of classmates, and academic self-concept. The acceptance of 
uncertainty factor comprises the variables of Tolerance for Uncertainty, Readiness for Risk, and Faith in Intuition.

The fitted model is shown in Figure 1. We used the pairwise maximum likelihood (pairwise ML). The model provided satisfactory fit: scaled $\chi^{2}=24.6, p>0.01(r=0.42)$, CFI (comparative fit index $)=0.98$, RMSEA (root mean square error of approximation) $=0.009$.

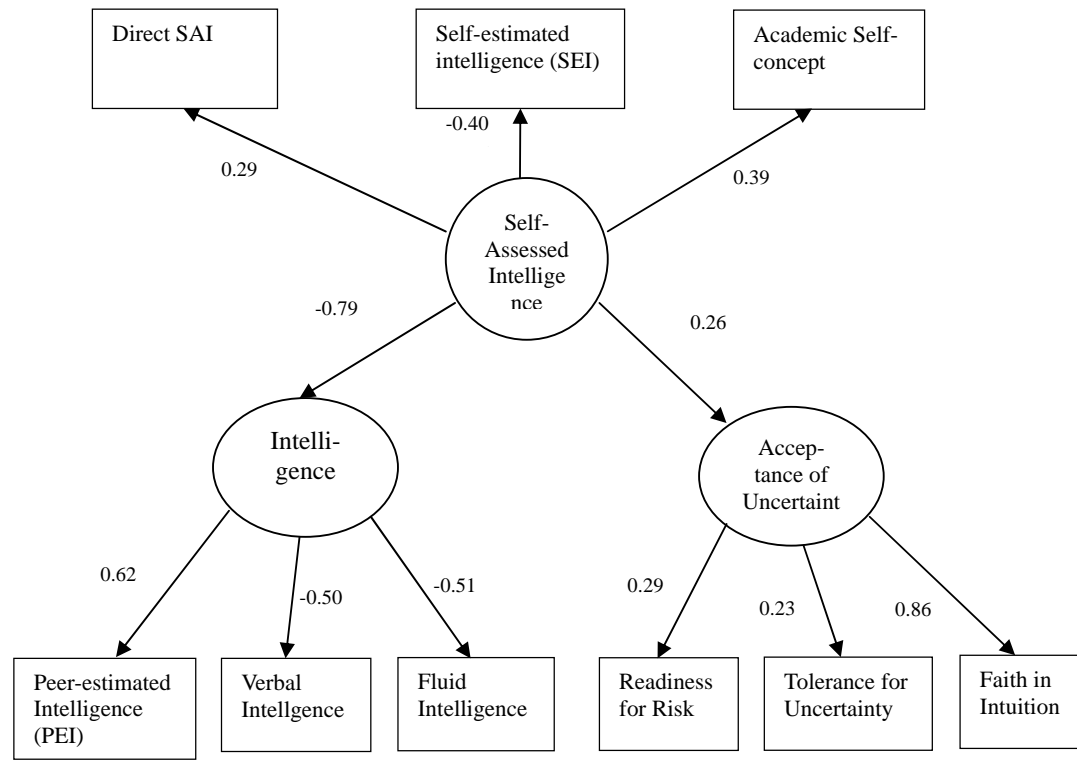

Figure 1. A diagram for the fitted model

Significant gender differences in direct SAI were obtained, $t=$ $-2.3, p<0.05$. Men estimated their intelligence higher than women; the average SAI score for men was 117.5 versus 112.5 for women. At the same time no difference between men and women in measured IQ was found; both groups had equal results, IQ scores of 100.5, on Wonderlic's CAT. The measures of fluid and verbal intelligence differed between men and women (men were 2 points higher in fluid IQ, and women were 3.5 higher in verbal IQ), but these differences turned out to be insignificant. 


\section{Discussion}

This study explored the relationship of subjective evaluations of intelligence, academic self-concept, conventional intelligence, and acceptance of uncertainty as a personality trait.

\section{Conclusions Based the Intercorrelations}

Several conclusions can be drawn based on the intercorrelations of the variables in the current study. First, the subjects' direct assessment of intelligence and academic self-concept positively correlate significantly with the subjects' fluid intelligence. PEI is positively correlated both with verbal and fluid intelligence and with SAI. From these facts we can draw the conclusion that people are aware to some extent of their cognitive ability and the cognitive ability of the people around them. Second, the above-mentioned correlations are significant but at the same time do not exceed $r=0.30$, which complies with Furnham's findings (Furnham, 2001; Chamorro-Premuzic \& Furnham, 2006a). Among other possible correlates of SAI we include such personal traits as acceptance of uncertainty. This finding seems to be logical; the situation of assessing one's own mind implies a high degree of uncertainty because of the lack of accurate reference points: each person decides individually whom to consider to be smart. Third, variables contributing to the subjective acceptance of uncertainty (such as Tolerance for Uncertainty, Readiness for Risk, and Faith in Intuition) do not correlate significantly with the variables of conventionally measured intelligence. Consequently we can conclude that SAI might be a possible mediator between the factors of measured IQ and personal traits such as acceptance of uncertainty. The structural model proposed in our study confirms this assumption. The factor of SAI is positively related to the factors of intelligence and acceptance of uncertainty. Because the links are bidirectional, we cannot choose between two possible interpretations of the empirical model. SAI might have an influence on intelligence and personality, and intelligence and acceptance of uncertainty can contribute to SAI.

In the empirical model the SAI factor is presented in several different dimensions: students' direct assessment of intelligence, estimation of IQ in the situation of social comparison with classmates, belief in the effectiveness of using their intelligence in an activity (studying). We didn't find any review of such an aggregated model of SAI in foreign studies. 
According to our results SAI reflects to some extent a real state: it reflects how smart a person is according to the results of IQ tests; this fact supports $\mathrm{H} 2$ of our study. PEI refers not to the SAI factor but to the factor of intelligence (which consists also of the conventionally measured intelligence variables: fluid and verbal IQ). This result is consistent with previously obtained data (Kornilova et al., 2009). Thus we can say that people judge intelligence (at least fluid and verbal abilities) by more or less the same criteria that underlie IQ tests. So the common idea that classmates tend to believe that the smartest student is not the one with the highest IQ can be doubted.

The factor of acceptance of uncertainty deserves a review. This factor comprises Readiness for Risk (acting under the constraints of information scarcity), Faith in Intuition (the tendency to believe first impressions and to have misgivings), and Tolerance for Uncertainty.

The factors of SAI and acceptance of uncertainty are positively related (thus $\mathrm{H} 1$ of our study is accepted). One can choose between two possible understandings of this correlation. Either people open to new experiences believe that this trait is related to cognitive ability and has a positive impact on it, or, on the contrary, those who estimate that their IQ is high are confident of their ability to solve problems that are new (unknown) to them.

In previous research the influence of IQ on SAI was discussed most often. We contend that the opposite interpretation is also possible. IQ might be influenced by SAI. As seen in our study, fluid and verbal intelligence manifest mostly in interactions with other people. It seems logical to suppose that people who assess their cognitive ability as being high tend to be involved more than others in social interactions and in such a manner develop their ability.

\section{Gender Differences}

H3 of our study implied significant gender differences in the level of SAI. This hypothesis was supported by the data. The difference between the direct SAI of men and that of women was 5 IQ points. At the same time there was no difference in general IQ score (which was 100.5 for both men and women).

Significant gender differences in SAI have been previously reported in a number of Western studies (Holling \& Preckel, 2005; Furnham et al., 2005) and might have as their source social factors or personal traits. 
It seems that in estimating their IQ Russian students truly follow social biases, according to which men are smarter than women. This bias seems somewhat ridiculous if we take into account the professional orientation of the sample: all the participants were students studying psychology and they were in the middle of their five-year university course. Despite the fact that they should have had a good knowledge of individual differences, they were still affected by the stereotypes.

Some researchers claim that the women's underestimation of their IQ poses a serious threat to their future careers because it might lead to significantly lower achievement than is possible. However, the academic performance of feminine students in this sample was significantly higher than the performance of the masculine students.

Thus we conclude that men estimate their IQ based on their achievement in fields that are not connected to studying in the university. An example of a similar effect is given by Anastasi: a review of more than 100 studies revealed higher correlations between the scores on ability tests and academic performance for women than for men (Anastasi \& Urbina, 1997). This evidence explains why academic performance is related to SAI in women but not in men.

\section{Conclusions}

1. SAI as a factor aggregates several different dimensions of people's assessment of their cognitive ability: direct estimation, estimation in comparison with peers, estimation in the context of an activity.

2. The SAI factor can be viewed as a mediating variable between intellectual potential and personality traits (namely, acceptance of uncertainty), being positively related to both of them.

3. Gender differences in SAI were obtained in the Russian sample. Men estimate their IQ significantly higher than do women. At the same time, no difference in measured IQ was found.

\section{References}

Ackerman, P.L., \& Heggestad, E.D. (1997). Intelligence, personality, and interests: evidence for overlapping traits. Psychological Bulletin, 121(2), 219-245.

Anastasi, A., \& Urbina, S. (1997). Psychological Testing (Seventh ed.). Upper Saddle River (NJ): Prentice Hall. 
Bandura, A. (1997). Self-efficacy: The exercise of control. New York: Freeman.

Belof, H. (1992). Mother, father and me: Our IQ. Psychologist, 5, 309-311.

Borozdina, L.V., \& Kubantseva, S.R. (2006). Pokazateli intellekta i neverbalnoy kreativnosti pri sootvetstvii i nesootvetstvii urovney samoocenki i pritayazaniy [Intelligence and nonverbal creativity in the situation of fitting and nonfitting of levels of selfesteem and desire]. Vestnik Moskovskogo Universiteta [Bulletin of Moscow University], Ser. 14 - Psychology, 4, 41-51.

Brunner, M., Krauss, S., \& Kunter, M. (2008). Gender differences in mathematics: Does the story need to be rewritten? Intelligence, 36, 403-421.

Burns, R.B. (1982). Self-concept development and education. New York: Holt, Rinehart \& Winston.

Buzin, V. N. (1992). Kratkiy orientirovochniy test [Cognitive Ability Test]. Moscow: Smysl.

Cattell, R. (1963). Theory of fluid and crystallized intelligence: A critical experiment. Journal of Educational Psychology, 54, 1-22.

Chamorro-Premuzic, T., \& Arteche, A. (2008). Intellectual competence and academic performance: Preliminary validation of a model. Intelligence, 36, 564-573.

Chamorro-Premuzic, T., \& Furnham, A. (2006a). Personality and self-assessed intelligence: Can gender and personality distort self-assessed intelligence? Educational Research and Reviews, 1(7), 227-233.

Chamorro-Premuzic, T., \& Furnham, A. (2006b). Self-assessed intelligence and academic performance. Educational Psychology, 26(6), 769-779.

Chesnokova, I.I. (1977). Problema samosoznaniâ v psihologii [The psychological problem of self-consciousness]. Moscow: Nauka.

Deary, I.J., Irwing, P., Der, G. \& Bates, T. (2007). Brother-sister differences in the g factor in intelligence: Analysis of full, opposite-sex siblings from the NLSY1979. Intelligence, 35, 451-456.

Deary, I.J., Dykiert, D., \& Gale, C.G. (2009). Are apparent sex differences in mean IQ scores created in part by sample restriction and increased male variance? Intelligence, 37, 42-47.

Duval, S., \& Wicklund, R.A. (1972). A theory of objective self awareness. New York: Academic Press.

Dweck, C.S. (1999). Self-theories: Their role in motivation, personality, and development. Philadelphia: Psychology Press.

Epstein, S., Pacini, R., Denes-Raj, V., \& Heier, H. (1996). Individual differences in Intuitive-Experiential and Analytical-Rational Thinking Styles. Journal of Personality and Social Psychology, 71(2), 390-405.

Flugel, J. (1947). An inquiry as to popular views on intelligence and related topics. British Journal of Educational Psychology, 27, 140-152. 
Furnham, A. (1994). A content, correlational and factor analytic study of four tolerance of ambiguity questionnaires. Personality and Individual Differences, 16, 403410.

Furnham, A. (2001). Self-estimates of intelligence: Culture and gender difference in self and other estimates of both general (g) and multiple intelligences. Personality and Individual Differences, 31(8), 503-517.

Furnham, A., Moutafi, J., \& Chamorro-Premuzic, T. (2005). Personality and intelligence: Gender, the Big Five, self-estimated and psychometric intelligence. International Journal of Selection and Assessment, 13(1), 11-24.

Furnham, A., \& Rawles, R. (1995a). Correlations between self-estimated and psychometrically measured IQ. Journal of Social Psychology, 139, 405-410.

Furnham, A., \& Rawles, R. (1995b). Sex differences in the estimation of intelligence. Journal of Social Behavior and Personality, 10, 741-745.

Furnham, A., \& Thomas, A. (2004). Parents' gender and personality and estimates of their own and their children's intelligence. Personality and Individual Differences, 37, 887-903.

Grigorenko, E.L. (1994). Modelirovanie s pomoshyu lineynih struktirnikh uravneniy [Linear structural equation modeling]. Psychological Issues, 4, 104-128.

Holling, H., \& Preckel, F. (2005). Self-estimates of intelligence - Methodological approaches and gender differences. Personality and Individual Differences, 38(3), 503517.

Kirckaldy, B., Noack, P., Furnham, A., \& Siefen, G. (2007). Parental estimates of their own and their children's intelligence. European Psychologist, 12(3), 173-180.

Kornilov, S. A., \& Grigorenko, E.L. (2010). Metodicheskij kompleks dlya diagnostiki analiticheskih, tvorcheskih i prakticheskih sposobnostej [The assessment battery for analytical, creative, and practical abilities]. Psihologicheskij Zhurnal [Journal of Psychology], 31(2), 90-103.

Kornilova, T.V. (2003). Psihologia riska i prinyatiya resheniy [Psychology of risk and decision making]. Moscow: Aspekt Press.

Kornilova, T.V. (2009). Novyj oprosnik tolerantnosti k neopredelennosti [The New Questionnaire of Tolerance for Uncertainty]. Psihologicheskij Zhurnal [Journal of Psychology], 30(6), 140-152.

Kornilova, T.V., Chumakova, M.A., Kornilov, S.A., \& Novikova, M.A. (2011). Psihologia neopredelennosti: Edinstvo intellektualno-lichnostnogo potenciala cheloveka [The psychology of uncertainty: The unity of the intellectual and personality potential of humans]. Moscow: Smysl.

Kornilova, T.V., Kornilov, S.A., \& Chumakova, M.A. (2009). Subjective evaluations of intelligence and academic self-concept predict academic achievement: Evidence from a selective student population. Learning and Individual Differences, 19(4), 596-608. 
Kornilova, T.V., Smirnov, S.D., Chumakova, M.V., Kornilov, S.A., \& NovototskayaVlasova, E.V. (2008). Modifikatsia oprosnika implitsitnikh teoriy C. Dweck (v kontekste izuchenia akademicheskikh dostizheniy studentov) [Modification of C. Dweck's implicit theories questionnaire (in the context of studying students' academic achievement)]. Psikhologisheskiy Zhurnal [Journal of Psychology], 29(3), 106-120.

Mead, G.H. (1934). Mind, self, and society. Chicago: University of Chicago Press.

Molchanova, O.N. (2006). Samoocenka: Stabilnost ili izmenchivost? [Self-esteem: Stability or fluidity?]. Psihologia. Zhurnal Vysshey Shkoli Ekonomiki [Psychology. Journal of High School of Economics], 3(2), 23-51.

Reilly, J., \& Mulhern, G. (1995). Gender differences in self-estimated IQ: The need for care in interpreting group data. Personality and Individual Differences, 18, 189-192.

Smirnov, S.D. (2005). Modificirovanniy variant metodiki K. Dveck dlâ ocenki tipov implicitnih teoriy intellekta i lichnosti, prisushih studentam [Modification of C. Dweck's implicit theories of intelligence and personality questionnaire for students]. Psihologia i Sociologia Obrazovania [Psychology and Sociology of Education], 82, 4055.

Smirnov, S.D., Kornilova, T.V., Kornilov, S.A., \& Malakhova, S.I. (2007). O svayazi intellektualnykh i lichnostnykh kharakteristik studentov s uspeshnostyu ih obucheniya [The relation between intellectual and personality characteristics of students and their academic achievement]. Vestnik Moskovskogo Universiteta [Bulletin of Moscow University], Series 14 - Psychology, 4, 82-88.

Sokolova, E.T. (1976). Motivaciya $i$ vospriyatie v norme i patalogii [Motivation and perception in the states of psychological norm and pathology]. Moscow: Moscow State University.

Stepanosova, O.V., Kornilova, T.V., \& Grigorenko, E.L. (2004). Diagnostika doveria intuicii [Diagnostics of faith in intuition]. Aktualnye problemy sovremennoy nauki: Socialnye i gumanitarnye nauki. Psihologia, kulturologia, iskusstvovedenie. Trudy 5-j mezhdunarodnoy konferencii molodykh uchenyh i studentov [Actual issues of contemporary science: Social and human sciences. Psychology, art and cultural studies. Materials of the $5^{\text {th }}$ International Conference of Young Scientists and Students]. Samara, Russia: SamGTU.

Sternberg, R. (1990). Metaphors of mind: Conceptions of the nature of intelligence. Cambridge, Great Britain: Cambridge University Press.

Sternberg, R., Conway, B., Ketron, J., \& Bernstein, M. (1981). People’s conceptions of intelligence. Journal of Personality and Social Psychology, 41, 37-55.

Stolin, V.V. (1983). Samosoznaniye liĉnosti [Self-consciousness of a person]. Moscow: Moscow State University. 